\title{
Determination of Aflatoxins in Sesame, Rice, Millet and Acha from Nigeria using HPLC
}

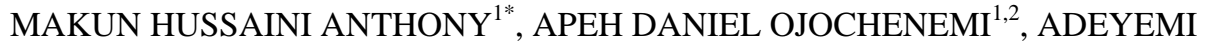 \\ HENRY RINDE YEMI ${ }^{1}$, NAGAGO TAHIR ${ }^{1}$, OKEKE JOHNBOSCO OKECHUKWU ${ }^{1}$, \\ MUSTAPHA AMINA SAIDU ${ }^{1}$ and OYINLOYE BUKUNMI AYOBAMI ${ }^{1}$
}

${ }^{1}$ Biochemistry Department, Federal University of Technology Minna, Niger State, Nigeria

${ }^{2}$ Family Health International (FHI360) Country Office, Abuja, Nigeria

danapeh@gmail.com

Received 12 October 2013 / Accepted 10 November 2013

\begin{abstract}
A hundred and twenty (120) Nigerian food commodities including; rice (15), madidi (rice product) (15), millet (15), fura (millet dough) (15), sesame (30) and fonio (30) were collected, subjected to aflatoxin extraction and clean up procedures and analyzed quantitatively for aflatoxins using High performance liquid chromatography. Five of the rice samples contained aflatoxin $\mathrm{B}_{1}$ within the range of 37.26-113.2 $\mu \mathrm{g} / \mathrm{kg}$, for madidi samples, 7 contained $\mathrm{AFB}_{1}$ within the range of $0.20-112.5 \mu \mathrm{g} / \mathrm{kg}, 3$ contained $\mathrm{AFB}_{2}$ within the range of $0.95-18.40 \mu \mathrm{g} / \mathrm{kg}$ while $6.88 \mu \mathrm{g} / \mathrm{kg}$ and 1.60 $\mu \mathrm{g} / \mathrm{kg}$ of the green fluorescing aflatoxins 1 and 2 respectively was found in one sample each. Analysis of sesame samples showed that eight contained $\mathrm{AFB}_{1}$ within the range of 14.71-140.9 $\mu \mathrm{g} / \mathrm{kg}$, while one sample contained $2.61 \mu \mathrm{g} / \mathrm{kg}$ of aflatoxin $\mathrm{G}_{1}$. The millet, millet dough and fonio samples all tested negative for the presence of aflatoxins indicating some degree of resistance. All contaminated rice and sesame samples were at ranges above the EU and Nigerian legislated limits for $\mathrm{AFB}_{1}$ and aflatoxins in food. This portrays associated health consequence to consumers and negative impact on trade of these commodities both locally and internationally.
\end{abstract}

Keywords: Aflatoxin, Rice, Millet, Fonio, Sesame

\section{Introduction}

Several episodes of aflatoxicosis has been put to record in human history, notably among which are the Western India outbreak of 1974 with 106 deaths of indigenous people whose staple food was maize, and the rural Kenya episode of 2004 which claimed the life of 125 natives of which aflatoxin-contaminated home grown maize was also responsible ${ }^{1-2}$. Apart from maize, aflatoxin have been reported in peanuts, rice, bread, cooked meats, sorghum, barley $^{3-7}$ and human milk as a function of the dietary exposure of the mother to $\mathrm{AFB}_{1}^{8-9}$. Aflatoxin are secondary metabolites of fungi belonging to the genera Aspergillus and it has been associated with the toxigenic members of the A. flavus, A. parasiticus, A. nomious, $A$. tamarii and $A$. ochraceoroseus ${ }^{10-11}$. Of the four aflatoxin subtypes, $\mathrm{AFB}_{1}$ is the most 
important in terms of occurrence and toxicity ${ }^{12-13}$. Aflatoxin have been associated with health effects including liver cancer, liver and kidney diseases, immunologic suppression, growth impairment among other disease conditions ${ }^{14-17}$.

Lack of awareness, management practices and toxin data necessary for legislative purposes, were possible causes of the Indian and Kenyan outbreaks until these lapses are fixed, a repeat of history is anticipated even in other part of the world. This should be taken seriously as human life is always involved directly or indirectly. Also worthy of attention is the current trend in global warming, which continuously provide warmer temperatures likely to provide optimum temperature which favours the growth of aflatoxigenic fungi ${ }^{18}$. Such temperature range as found in the tropical and subtropical regions together with relative humidity of over $70 \%$ significantly favours the growth of moulds. Aflatoxin contamination can occur during crop development when the crop is either damaged (e.g., by insects) or stressed by heat and drought and after maturation when the crop is exposed to high moisture and high temperature either before harvest or in storage $\mathrm{e}^{19-20}$. The death rates in the reported episodes above were directly related to high dependence on maize as the major staple in those regions. Over time, dependence on maize has subsided due to the recognition of the nutritional value of other staples such as rice, millet and fonio. Sesame is also consumed widely in different forms. Also this energy sources are less susceptible to fungal and aflatoxin ${ }^{21}$.

Fonio locally referred to as "acha” is a very old African crop cultivated for its nutritional attributes including high amino acids content particularly methionine which is twice that in egg protein ${ }^{22}$ and cystine which supply sulfur and other compounds required by the body for normal metabolism and growth ${ }^{23}$. Fonio is also rich in phenylalanine, another essential amino acid ${ }^{24}$ and can therefore potentially replace legumes to complement standard diets. Fonio is one of the grains with very high magnesium, zinc and manganese levels. Comparatively, it is significantly richer in vitamins $\mathrm{B}_{1}$ and $\mathrm{B}_{2}$, calcium and phosphorous than white rice ${ }^{25}$. Out of the total world production of 583,882 metric tonnes, Nigeria produced 90,000 metric tonnes in the 2012 fiscal year amounting to $15.41 \%$, making her the world second largest producer after Guinea, an improvement over the previous 80,000 metric tonnes it produced in 2011. Consumption of this grain is also high locally as it is consumed as porridge.

Sesame (Sesamum indicum L.) commonly known as beniseed is one of the oil seeds cultivated in Nigeria, being the eight and fifth largest sesame producer in the world and in Africa respectively. Nigeria contributes 158,000 metric tonnes in a world total of 4,167,150 metric tonnes. From its introduction after the Second World War, it was regarded as a crop of insignificant importance compared to groundnut and other cash crops until about 1974 when it became one of the major cash crops in many Northern Nigerian states ${ }^{26}$. Sesame has continued to gain increased recognition due to the presence of omega-3-fatty acid, essential oils as well as natural antioxidant sesame in that both prevent aging and is vital to liver cell production. Dietary supplement of $40 \mathrm{~g}$ per day lowers serum total cholesterol and low density lipoprotein cholesterol and consequently protects hypercholesterolemic patients from atherosclerosis $^{27,28}$. Sesame oil has been shown to ameliorate cough in children ${ }^{29}$. It is also rich in protein with amino acid profile similar to soybean. These sterling attributes recently discovered, are stimulating interest in the production of the crop. Owing to its previous status as a minor crop, there has been little research efforts on the crop so far. From Nigeria, sesame is exported majorly as seed and the destination is majorly Asia ranking amongst the top 5 exported products. Sesame seed has the risk of contamination during storage by mycotoxins especially the ubiquitous and hepatotoxic aflatoxins, which are produced when 
seeds and nuts are kept under conditions that favour the development of these fungi. Contamination of sesame seed along the supply chain is of major concern for public health and trade.

Eighty countries produced 25, 597, 550 metric tonnes of millet in 2012, the contribution of Nigeria was 1,000,100 metric tonnes making it the sixth largest producer after India, Niger, Mali, China and Burkina Faso in the year under review. Millet remains a key source for food security and energy for about 250 million people in sub-Saharan Africa. It is consumed after it has been processed into various forms of meal, biscuit, gruel, cake pap and porridge $^{30}$. The susceptibility of millet to fungal growth and mycotoxin contamination has been documented ${ }^{31,32}$. The limited mycotoxin research on millet in Africa is understandable as it is one of the 'lost crops of Africa' neither is it an export crop. However, its protein and vitamin contents, resistance to drought and resistance to mycotoxin contamination has brought this African traditional crop to the front burner of research worldwide because it is anticipated to boost food production in poverty and drought stricken regions of the world as well as reduce the economic and health risks to food spoilage organisms and toxins ${ }^{33}$.

Rice (Oryza sativa) is a major staple in many part of the world and has been patronized at world levels with a large market. The world total rice production in 2012 was 718,345,380 metric tonnes of which, Nigeria with status as the second world leading rice importer, produced about 4,833,000 metric tonnes making her the seventeenth of over one hundred and seventeen producing countries. Rice is grown approximately on 3.7 million hectares in Nigeria, covering $10.6 \%$ of the 35 million hectares of land under cultivation, out of a total arable land area of 70 million hectares ${ }^{34}$. In terms of calorie rice was the fourth most important crop in Nigeria between 2000 and 2007 after sorghum, millet and cassava ${ }^{34 .}$

Aflatoxin contamination constitutes a major setback to export trade in grains and cereals proceeding from Africa, as a result it poses a challenge to food security in areas that are dependent on these staples. This is due to available legislative limits provided by different countries. Considering their health and economic implications, there is therefore the need to elucidate the mycotoxin profile of these crops within regions where they are produced and marketed, with a view to generating incidence data which can be used to proffer intervention strategies. The objective of this study therefore is to determine the aflatoxin content of sesame, millet, fonio, rice and some of their products produced and marketed in Northern Nigeria.

\section{Experimental}

Sampling was conducted between the months of June and July, 2012. About 500 g each of 120 food samples were collected thus; Fifteen (15) samples each of rice and madidi (rice product) were randomly collected from various locations in Nasarawa state. Thirty (30) samples each of fonio and sesame seeds were collected from four markets within Minna, Niger state, 15 samples each of millet and millet dough were also collected from Kontagora in Niger state. All samples were sealed in plastic bottles and stored at $-20^{\circ} \mathrm{C}$ in deep freezer before analysis.

\section{Extraction of Aflatoxin and Clean-up}

The extraction method of Ehrlich et al. ${ }^{35}$ was used. This method uses methylene chloride and phosphoric acid for the simultaneous extraction of aflatoxin $B_{1}, B_{2}, G_{1}, G_{2}$ and OTA, which is then subjected to specific clean up procedure for aflatoxins as elaborated thus; Twentyfive grams ( $25 \mathrm{~g}$ ) portion of pulverized sample/paste equivalent was weighed/poured into $500 \mathrm{~mL}$ Erlenmeyer flask. One molar phosphoric acid $(12.5 \mathrm{~mL})$ and methylene chloride 
(125 mL) was added. The flask was covered with a stopper and shaken for 30 minutes. The content was then filtered on a funnel fitted with Whatmann No. 1 filter paper. About $120 \mathrm{~mL}$ of the filtrate was collected and from this, $50 \mathrm{~mL}$ aliquot each was placed in separate $100 \mathrm{~mL}$ Erlenmeyer flasks with glass stoppers ready for clean-up.

During clean-up, a separating column was set with glass wool, into which $150 \mathrm{~mL}$ of methylene chloride $\left(\mathrm{CH}_{2} \mathrm{Cl}_{2}\right)$ was poured and drained halfway through one scoop of anhydrous sodium sulphite $\left(\mathrm{Na}_{2} \mathrm{SO}_{4}\right)$ on the filter paper. The remaining methylene chloride was drained then silica gel was added into the column and $80 \mathrm{~mL}$ methylene chloride was poured in and allowed to settle before it was drained half way. Three scoops of sodium sulphite were added and the remaining half of the methylene chloride was drained completely. Filtrate sample ( $25 \mathrm{~mL}$ ) was added and drained completely, $65 \mathrm{~mL}$ of $n$-hexane was added and drained, $65 \mathrm{~mL}$ of petroleum ether was also added and drained. $65 \mathrm{~mL}$ of solvent consisting of petroleum ether, methanol and water in the ratio (96:3:1) was added and drained into a clean beaker. This portion now containing the toxin was evaporated to about $2 \mathrm{~mL}$ and finally dispensed in an amber bottle and refrigerated for HPLC analysis.

\section{High Performance Liquid Chromatography}

Agilent technologies 1200 series HPLC fitted with Octadecylsilyl groups (ODS), (4.6150mm-5um) column set at ambient temperature with mobile phase being acetonitrile:water:methanol $(10: 50: 40 \mathrm{v} / \mathrm{v})$ was used. The machine flow rate was set at $0.8 \mathrm{~mL} / \mathrm{min}$ and the sample Injection volume was $20 \mu \mathrm{L}$. The detection limit of the machine with regards to the aflatoxin was $0.1 \mu \mathrm{g} / \mathrm{kg}$ and the recoveries for each of the toxins were greater than $85 \%$.

\section{Statistical analysis}

All the analytical data generated were subjected to statistical analysis using SPSS (version 16.0) software. The statistical level of significance was fixed at $\mathrm{P}<0.05$ (95\%)

\section{Results and Discussion}

Aflatoxin producing fungi such as Aspergillus flavus thrive on several food commodities in Nigeria $^{7,18,36,37}$. In sesame samples, low incidence $(8 / 30)$ of aflatoxin was observed with high concentration in positive samples (Table 1). All contaminated sesame samples were at levels above the EU maximum limits of $2 \mu \mathrm{g} / \mathrm{kg}$ for aflatoxin $\mathrm{B}_{1}$ and $4 \mu \mathrm{g} / \mathrm{kg}$ for total aflatoxin. The EU limit has been adopted and is currently used as the standard in Nigeria. However, the Nigerian limit was $10 \mu \mathrm{g} / \mathrm{kg}$ for total aflatoxin before now. Aflatoxin $\mathrm{B}_{1}$, was found at Mean $\pm S E M$ value of $18.59 \pm 6.57 \mu \mathrm{g} / \mathrm{kg}$. Only one sample was contaminated with aflatoxin $\mathrm{G}_{1}$ at $2.61 \mu \mathrm{g} / \mathrm{kg}$. Thus the ratio of occurrence is $1: 0.14$ for $\mathrm{AFB}_{1}: \mathrm{AFG}_{1}$. This presents a slight deviation from the reported natural occurrence of aflatoxin being 1.0: 0.1: 0.3: 0.03 for $\mathrm{AFB}_{1}$, $\mathrm{AFB}_{2}, \mathrm{AFG}_{1}, \mathrm{AFG}_{2}$ respectively ${ }^{39,40}$. Studies on aflatoxin in sesame in Nigeria includes that of Ezekiel et al., ${ }^{41}$ who demonstrated that sesame is less susceptible to aflatoxin presenting an incidence of 0/17 and that of Mbah and Akuesi ${ }^{18}$ who incubated two species of sesame with Aspergillus flavus and found that only 4 out of 60 samples were contaminated with about 25 ppb of aflatoxin $B_{1}$ after 20 days of incubation. Both studies indicate low susceptibility of sesame to aflatoxin, despite the fact that the high oil content of sesame is perceived to make it a good substrate for fungal growth ${ }^{40}$. Our work further demonstrates low aflatoxin incidence (8/30) however at unsafe levels. Factors responsible for this difference could be attributed to difference in geographical region of sampling, as both authors ${ }^{18,41}$ sampled from Plateau state Nigeria. Plateau state is known for a relatively low temperature and 
high relative humidity all year round when compared to Niger state were we sampled. Contamination could also result from poor handling and unwholesome practices along the post-production chain.

Table 1. Aflatoxin concentrations in samples of dry sesame seed, rice and rice product (Madidi), fonio, millet and millet dough (fura) $(\mu \mathrm{g} / \mathrm{kg}$ ) and their safety status

\begin{tabular}{|c|c|c|c|c|c|c|c|}
\hline $\begin{array}{l}\text { Sample Type/ } \\
\text { Frequency }\end{array}$ & $\begin{array}{l}\text { Sample } \\
\text { Code }\end{array}$ & $\begin{array}{l}\mathrm{AFB}_{1} \\
\mu \mathrm{g} / \mathrm{kg}\end{array}$ & $\begin{array}{l}\mathrm{AFB}_{2} \\
\mu \mathrm{g} / \mathrm{kg}\end{array}$ & $\begin{array}{l}\mathrm{AFG}_{1} \\
\mu \mathrm{g} / \mathrm{kg}\end{array}$ & $\begin{array}{l}\mathrm{AFG}_{2} \\
\mu \mathrm{g} / \mathrm{kg}\end{array}$ & $\begin{array}{l}\text { Total } \\
\text { AF }\end{array}$ & $\begin{array}{l}\text { Safety } \\
\text { Status }\end{array}$ \\
\hline \multirow[t]{8}{*}{ Rice (5/15) } & $\mathrm{R} 1$ & 37.26 & & & & 37.26 & Unsafe \\
\hline & $\mathrm{R} 4$ & 40.24 & & & & 40.24 & Unsafe \\
\hline & R7 & 113.20 & & & & 113.2 & Unsafe \\
\hline & R13 & 75.38 & & & & 75.38 & Unsafe \\
\hline & R15 & 112.40 & & & & 112.4 & Unsafe \\
\hline & Range & $\begin{array}{l}37.26- \\
113.20\end{array}$ & & & & & \\
\hline & Mean \pm & $75.38 \pm 37.0$ & & & & & \\
\hline & SD & 4 & & & & & \\
\hline \multirow[t]{11}{*}{ Madidi (8/15) } & M1 & 1.00 & 1.40 & 6.88 & 1.60 & 10.88 & Unsafe \\
\hline & M3 & 1.40 & & & & 1.40 & \\
\hline & M7 & 8.30 & & & & 8.30 & Unsafe \\
\hline & M8 & 0.20 & & & & 0.20 & safe \\
\hline & M9 & & 0.95 & & & 0.95 & safe \\
\hline & M11 & 1.40 & & & & 1.40 & safe \\
\hline & M14 & 125.60 & 18.40 & & & 144.0 & Unsafe \\
\hline & M15 & 2.84 & & & & 2.84 & Unsafe \\
\hline & Range & $0.2-125.60$ & $0.95-18.4$ & & & & \\
\hline & Mean \pm & $20.11 \pm 46.6$ & $6.92 \pm 9.95$ & & & & \\
\hline & SD & 0 & & & & & \\
\hline \multirow{10}{*}{$\begin{array}{l}\text { Dry Sesame } \\
\text { seed }(8 / 30)\end{array}$} & SS1 & 40.00 & & 2.61 & & 42.61 & Unsafe \\
\hline & SS2 & 14.71 & & & & 14.71 & Unsafe \\
\hline & SS3 & 49.39 & & & & 49.39 & Unsafe \\
\hline & SS4 & 59.98 & & & & 59.98 & Unsafe \\
\hline & SS5 & 140.90 & & & & 140.9 & Unsafe \\
\hline & SS6 & 49.04 & & & & 49.04 & Unsafe \\
\hline & SS7 & 111.44 & & & & 111.4 & Unsafe \\
\hline & SS8 & 92.26 & & & & 92.26 & Unsafe \\
\hline & Range & $14.71-140.90$ & & & & & \\
\hline & $\begin{array}{l}\text { Mean } \pm \\
\text { SD }\end{array}$ & $69.72 \pm 41.68$ & & & & & \\
\hline Millet (0/15) & M1-M15 & ND & ND & ND & ND & NA & Safe \\
\hline $\begin{array}{l}\text { Millet dough } \\
\text { (fura) }(0 / 15)\end{array}$ & $\begin{array}{l}\text { MD1- } \\
\text { MD15 }\end{array}$ & ND & ND & ND & ND & NA & Safe \\
\hline Fonio $(0 / 30)$ & F1-F15 & ND & ND & ND & ND & NA & Safe \\
\hline
\end{tabular}

$N D$ - not detected; NA - not applicable

Information on aflatoxin contamination of rice worldwide including few from some parts of Nigeria are available ${ }^{32,42,43}$ with some unpublished. However, to the best of our knowledge in Nasarawa state of Nigeria, no study on aflatoxin in rice has been carried out neither has any work been done on aflatoxin in madidi (rice product). In this study, rice 
samples tested positive for aflatoxins $B_{1}, B_{2}, G_{1}$ and $G_{2}$ at low incidence; 5/15 for rice and $7 / 15$ for madidi. Generally, a lower aflatoxin concentration was found in madidi when compared to rice. This drop in aflatoxin may be due to the processes involved in the production of madidi; soaking and heating. Soaking and subsequent decantation has been shown to reduce aflatoxin levels ${ }^{44,45}$. Aflatoxin $B_{2}$ was also found in $3 / 15$ madidi samples at concentrations ranging between $0.95-18.40 \mu \mathrm{g} / \mathrm{kg}$. $\mathrm{AFG}_{1}$ and $\mathrm{AFG}_{2}$ were present in one sample each of madidi at concentrations of $6.88 \mu \mathrm{g} / \mathrm{kg}$ and $1.60 \mu \mathrm{g} / \mathrm{kg}$ respectively. The early work of Opadokun ${ }^{40}$ showed a low incidence (13/279) of $\mathrm{AFB}_{1}$ in rice samples with mean value of $5 \mu \mathrm{g} / \mathrm{kg}$ lower than what was found in this work. Makun et al. ${ }^{43}$ using a very sensitive method of analysis, found each of $A_{F} B_{1}, B_{2}, G_{1}$ and $G_{2}$ in at least 19 of 21 rice samples from Niger state. Other works especially on fungi profile have also demonstrated risk of aflatoxin contamination in rice ${ }^{43}$.

All the fonio, millet and millet dough (fura) samples analyzed showed noaflatoxin contamination, probably because they are present below detectable limit despite the sensitivity of the method used. Available reports indicate either low incidence and/or concentrations of aflatoxin in fonio, among these are Ezekiel et $a .^{41}$ who had a high incidence (81\%) but low levels (0.08-1.4 $\mu \mathrm{g} / \mathrm{kg}$ ) below the EU maximum limit and Gbodi et al. ${ }^{46}$ who reported low incidence of $4 / 24$ and $2 / 24$ for both $\mathrm{AFB}_{1}$ and $\mathrm{AFB}_{2}$ at range of $0-20$ $\mu \mathrm{g} / \mathrm{kg}$ and $0-12 \mu \mathrm{g} / \mathrm{kg}$ respectively of aflatoxin in fonio. In Nigeria, aflatoxin contamination of millet has also been reported however at low incidence which were found mostly at unsafe concentrations ${ }^{42,43,47}$. Other studies on aflatoxin in millet outside Nigeria include the works of Mishra and Daradiyhar ${ }^{48}$ and Wilson et al. ${ }^{49}$ who also reported aflatoxin $\mathrm{B}_{1}$ at unsafe levels in stored millet, cooked millet and pearl millet,with highest levels of toxin in stored millet, thus reiterating the importance of providing proper storage conditions which will not favour the growth of fungi and mycotoxin production. Part of the reason for the low levels of aflatoxin earlier reported in millet and fonio as well as the low susceptibility found in this work is not unrelated to their phytochemical compositions. Viswanatha et al. ${ }^{50}$ showed that phenolic compounds in the seed coat of millet are active against fungi giving millet some antifungal attributes. It was also well stated that phenolic including tannins which are present in this grains are involved in grain resistance to fungi attack ${ }^{51}$. Also, the tiny nature of millet and fonio attributes them small surface area for mould infestation this in turn, reduces their susceptibility to mycotoxins significantly ${ }^{52}$.

Exposure to aflatoxin in West Africa is widespread, blood tests have shown that very high percentage of West Africans are exposed to aflatoxin ${ }^{53}$. In a study carried out in the Gambia, Guinea Conakry, Nigeria and Senegal, over 98\% of subjects tested positive to aflatoxin markers ${ }^{53}$. This is attributed to high dependence on aflatoxin susceptible foods including but not strictly restricted to maize, sorghum and rice in this region. Aflatoxin is a very powerful hepatocarcinogen, and naturally occurring mixtures of aflatoxins as found in some sesame and madidi samples in our work has been identified as a class 1 human carcinogen ${ }^{8}$.

The impact of the presence of AF in rice and sesame on health and trade in Nigeria cannot be overstated, this is because of the high consumption rate of both products among nationals and also due to international trade demand of this products. On average between the fiscal year 2000-2007 rice was the $4^{\text {th }}$ most important crop in terms of calories following sorghum, millet and cassavain Nigeria. Being both a food and a cash crop for local farmers, it contributes to small holders revenues in the main producing areas. WARDA estimates that per capita rice consumption in Nigeria has nearly doubled between the 1980s and 2006, growing from $15.4 \mathrm{~kg} /$ year to $25.4 \mathrm{~kg} /$ year $^{54}$ this figure tells of the impending danger in 
continuous consumption of aflatoxin infested grains. In 2011 alone, Nigeria exported about 166 tonnes of rice valued at $\$ 3000$ and 124,700 tonnes of sesame valued at $\$ 148,613,000$ this figure especially for sesame can be improved on if fungi and aflatoxin contamination is reduced and managed properly.

Based on our findings, we recommend the diversification of diet such that over dependence on crops that are highly susceptible to aflatoxin is reduced. Fonio and millet should be incorporated as energy sources especially in the regions were we sampled. This will however require proper orientation and awareness campaign on the impending danger of over dependence on the major staples (maize and sorghum) of the region which have been shown to be susceptible to fungi that produce aflatoxin. This if practiced will to a great extent reduce aflatoxin ingestion and associated health hazards.

\section{Conclusion}

Five of fifteen rice samples contained $\mathrm{AFB}_{1}$ at levels above the $\mathrm{EU}$ and Nigerian legislative limits. Seven madidi samples contained $\mathrm{AFB}_{1}$ while three contained $\mathrm{AFB}_{2}$, one each contained $\mathrm{AFG}_{1}$ and $\mathrm{AFG}_{2}$ respectively. The trend in the study shows a general reduction in aflatoxin concentration from rice grain to rice product (madidi) as a result of processing. Eight of thirty sesame samples contained $\mathrm{AFB}_{1}$ also above the safe level, while one sample contained $\mathrm{AFG}_{1}$. The incidence was low for both crops but the concentrations were mostly above the permitted legislative limits. Considering the aforementioned, it is therefore, needful to employ good agricultural practices (GAPs) both before and after crop harvesting as well as lay more emphasis on proper monitoring activities. Also the fact that levels of the toxins found were at concern levels should trigger enforcement of regulations by concerned national bodies that are responsible for setting standards and those responsible for enforcing set standards.

\section{Acknowledgement}

The Authors are grateful to the laboratory staff of the Department of Biochemistry, Federal University of Technology, Minna, Niger state for the technical assistance rendered.

\section{References}

1. Bhumi N R and Chinnam R R, African Journal of Food Agriculture Nutrition and Development, 2007, 7(5). Available on http://www.bioline.org.br/request?nd07046

2. Azziz-Baumgartner E, Lindblade K, Gieseker K, Rogers H S, Kieszak S, Njapau H, Schleicher R, McCoy L F, Misore A, KevinDeCock, Rubin C and Slutsker Environmental Health Perspectives, 2005, 113(12), 1779-1783; DOI:10.1289/ehp.8384

3. Bullerman L B, J Food Protocols, 1979, 42, 65-86.

4. Payne G A., Siriha K K and Bharnagar D, Ed., Marcel Dekker, Inc., New York, NJ, USA, 1998, pp. 279-306.

5. Kpodo K, Thrane U and Hald B, Int J Food Microbiol., 2000, 61(2-3), 147-157; DOI:10.1016/S0168-1605(00)00370-6

6. Fandohanda P, Zoumenou D, Hounhouigan D J, Marasas W F O, Wingfield M J and Hell K, Int J Food Microbiol., 2004, 98(3), 249-259; DOI:10.1016/j.ijfoodmicro.2004.07.007

7. Makun H A, Gbodi T A, Akanya O H, Salako A E and Ogbadu G H, AfrJ Food Sci., 2009, 3(9), 250-256.

8. IARC, IARC Monographs on the Evaluation of Carcinogenic Risk of Chemicals to Humans, Lyon, France: International Agency for Research on Cancer, 1993, 56, 245. 
9. Sweeney M J, White S, and Dobson A D W, Irish J Agr Food Res., 2000, 39(2), 235-244

10. Ehrlich K C, Kobbeman K, Montalbano B G, and Cot P J, Int J Food Microbiol., 2007, 114(2), 153-159; DOI:10.1016/j.ijfoodmicro.2006.08.007

11. Klich M A, Mullaney E J, Daly C B and Cary J W, Appl Microbiol Biotechnol., 2000, 53(5), 605-609; DOI:10.1007/s002530051664

12. Detroy R W, Lillehoj E B and Ciegler A, In: Ciegler A, Kadis S and Ajl S J, (Eds.), Microbial Toxins, New York: Academic Press, 1971, p6.

13. Abdel-Wahhab M A, Nada S A and Khalil F A, Animal Feed Sci Technol., 2002, 97(3-4), 209-219; DOI:10.1016/S0377-8401(01)00342-X

14. IARC, In press, IARC, Lyon IARC Monographs on the Evaluation of Carcinogenic Risks to Humans: Traditional Herbal Medicines, Some Mycotoxins, Napthalene and Styrene, 2002, 82.

15. Wagacha J M and Muthomi J W, Int J Food Microbiol., 2008, 214(1), 1-12; DOI:10.1016/j.ijfoodmicro.2008.01.008

16. Murphy P A, Hendrich S, Langren C and Bryant C M, J Food Sci., 2006, 71(5), 51-65; DOI:10.1111/j.1750-3841.2006.00052.x

17. Khlangwiset P, Shephard G S and Wu F, Crit Rev Toxicol., 2011, 41(9), 740-755; DOI:10.3109/10408444.2011.575766

18. Mbah M C and Akueshi C O, Afr J Biotechnol., 2009, 8(3), 391-394; DOI:10.5897/AJB2009.000-9067

19. Payne G A and Widstrom N W, Crit Rev Plant Sci., 1992, 10(5), 423-440; DOI:10.1080/07352689209382320

20. Atehnkeng J, Ojiambo P S, Ikotun T, Sikora R A, Cotty P J and Bandyopadhyay R, Food Additives \& Contaminants: Part A, 2008, 25(10), 1264-1271; DOI:10.1080/02652030802112635

21. Hell K, Fandohan P, Bandyopadhyay R, Kiewnick S, Sikora R and Cotty P J, In: Leslie J F, Bandyopadhyay R and Visconti A, Editors, (Wallingford: CABI Publ), 2008, 219-229.

22. O’Kennedy M M, Grootboom A and Shewry P R, J Cereal Sci., 2006, 44(3), 224-235; DOI:10.1016/j.jcs.2006.08.001

23. Belton P S and John R N, Publisher Springer-Verlag Berlin Heidelberg, 2002, 201.

24. Bavec F and Bavec M, Organic Production and Use of Alternative, Crops, CRC Press/Taylor and Francis,2006, p214; DOI: 10.1017/S001447970637490x

25. Kuta D D, Kwon-Ndung E, Dachi S, Ukwungwu $M$ and Imolehin E D, Afr $J$ Biotechnol., 2003, 2(12), 580-585; DOI:10.5897/AJB2003.000-1111

26. NAERLS (National Agricultural Extension and Research Liaison Services) Ahmadu Bello University, Zaria, 2004.

27. Chen P R, Lee C C, Chang H and Tsai C E, J Nutri Biochem., 2005, 16(1), 59-64; DOI:10.1016/j.jnutbio.2004.07.008

28. Visavadiya N P and Narasimhacharya A V R L, Food Chem Toxicol., 2008 46(6), 1889-1896; DOI:10.1016/j.fct.2008.01.012

29. Saab B R, Pashayan N, El-Chemaly S and Ramzi Sabra, Complement Ther Med., 2006, 14(2), 92-99; DOI:10.1016/j.ctim.2006.03.007

30. Eneche E H, Plant Foods Human Nutrition, 1999, 54(1), 21-27; DOI:10.1023/A:1008031618117

31. Okoye Z S C, Biochemical Aspects of Nutrition Prentice-Hall of India, New Delhi. 1992, 147, 155.

32. Makun H A, Gbodi T A, Tijani A S, Abai A and Kadiri G U, Afr J Biotechnol., 2007, 6(1), 034-040; DOI:10.5897/AJB07.633 
33. Bandyopadhyay R, Kumar M and Leslie J F, Food Additives Contaminants Part A, 2007, 24(10), 1109-1114; DOI:10.1080/02652030701553251

34. Cadoni P and Angelucci F, Technical notes series, MAFAP, FAO, Rome, 2013.

35. Ehrlich K C, Lee L S and Ciegler A, Appl Envir Microbiol., 1982, 44(4), 1007-1008.

36. Jonathan S G and Esho E O, Electro J Environ, Agr Food Chem., 2010, 9(11), 1722- 1730.

37. Makun H A, Anjorin S T, Moronfoye B, Adejo F O, Afolabi O A, Fagbayibo, G, Balogun B O and Surajudeen A A, Afr J Food Sci., 2010, 4(4), 127-135.

38. Abbas H K, Reddy K R N, Salleh B, Saad B, Abel C A and Shier W T, Toxin Rev., 2010, 29(1), 3-26; DOI:10.3109/15569541003598553

39. Kensler T W, Roebuck B D, Wogan G N and Groopman J D, Toxicological Sciences, 2011, 120(1), S28-S48; DOI:10.1093/toxsci/kfq283

40. Luttfullah G and Hussain A, Food Control., 2011, 22(3-4), 426-429; DOI:10.1016/j.foodcont.2010.09.015

41. Ezekiel C N, Sulyok M, Warth B, Odebode A C and Kriska R, Food Control., 2012, 27(2), 338-342; DOI:10.1016/j.foodcont.2012.04.010

42. Opadokun J S, $1^{\text {st }}$ National Workshop on Mycotoxins, 29 ${ }^{\text {th }}$ November, 1990 at University of Jos Nigeria. Book of proceeding, 1992, pp. 50-60.

43. Makun H A, Dutton M F, Njobeh P B, Mwanza M and Kabiru A Y, Mycotoxin Research, 2011, 27(2), 97-104; DOI:10.1007/s12550-010-0080-5

44. Yahl K R, Watson S A, Smith R J and Barabolok R, Cereal Chem., 1971, 48, 385-391.

45. Romer T, Feedstuffs, 1984, 56(37), 22-23.

46. Gbodi T A, Nwude N, Aliu Y O and Ikediobi C O, Food Chem Toxicol., 1986, 24(4), 339-342; DOI:10.1016/0278-6915(86)90012-8

47. Nwokolo C and Okonkwo P, Trans Roy Soc Trop Med Hyg., 1978, 72(4), 329-332; DOI:10.1016/0035-9203(78)90119-0

48. Mishra N K and Daradhiyar S K, Appl Environ Microbiol., 1991, 57(4), 1223-1226

49. Wilson J P, Jurjevic Z, Hanna W W, Wilson D M, Potter T L and Coy A E, Mycopathologia, 2006, 161(2), 101-107; DOI:10.1007/s11046-005-0170-7

50. Viswanatha V, Urooja A and Malleshib N G, Food Chem., 2009, 114(1), 340-346; DOI:10.1016/j.foodchem.2008.09.053

51. Seetharam A and Ravikumar R L, In: Riley K W, Gupta S C, Seetharamn A and Mushonga J N, (Eds.), International Science Publisher, New York, 1994, 449-465.

52. Jones F T and Hamilton P B, Poult Sci., 1987, 66(9), 1545-1547; DOI:10.3382/ps.0661545

53. Wild C P, Hasegawa R, Barraud L, Chutimataewin S, Chapot B, Ito N and Montesano R, Cancer Epidemiol Biomarkers Prev., 1996, 5(3), 179-189.

54. Warda J, OECD Science, Technology and Industry Working Papers, OECD Publishing, 2006, 4. 